\title{
Governance, Time Preference, and Collective Maintenance: The Case of Small-scale Irrigation in Northern Ghana
}

\author{
Margaret Atosina Akuriba \\ University for Development Studies \\ Rein Haagsma \\ Wageningen University and Reseach \\ Nico Heerink \\ Wageningen University and Research
}

\begin{abstract}
Small-scale irrigation schemes in northern Ghana are managed by Water User Associations (WUAs). Maintenance of these schemes is a collective effort by WUA members. We argue that individual labour contributions to maintenance depend on perceptions of the prevailing WUA governance strategies and on time preferences of WUA members. We empirically estimate these relationships using data collected through a household survey and a field experiment held in 18 small-scale irrigation schemes. We find that governance perceptions of conflict management and equity and fairness positively associate with labour contributions, while the (negative) association of time preferences is not statistically significant.
\end{abstract}

Keywords: irrigation, labour contributions, governance perceptions, rural livelihoods, Northern Ghana

\section{INTRODUCTION}

For poor rural populations that depend to a large extent on agriculture for their livelihoods, increased productivity is critical in reducing poverty. Irrigated agriculture is commonly regarded as a major way to increase agricultural productivity (Namara et al., 2011; Dittoh et al., 2013; Mengistie and Kidane, 2016). Given the low prevalence of irrigated agriculture in Africa, investments in irrigation infrastructure geared towards poverty reduction and improved food security are urgently needed (e.g. Gachunga and Kuso, 2019; Oates et al., 2015; Svendsen et al., 2009).

Irrigation schemes can be considered as so-called common pool resources (CPRs) (Bravo and Marelli, 2008; Ostrom, 2000; Yu et al., 2016), which are mostly used by groups of people or communities. Small-scale irrigation schemes in Africa and elsewhere are increasingly managed by these users themselves, often in the form of Water User Associations (WUAs) or irrigation management committees (Mutambara et al., 2016). The daily activities of these user groups play a critical role in the sustainability of the schemes. The underperformance and unsustainability of most irrigation facilities in Africa has partly to do with the poor operation and maintenance by user groups (Mutambara et al., 2016; Namara et al., 2011; Lamptey et al., 2011). 
Proper maintenance requires governance strategies that curtail free riding among those who have to partake in maintenance, and governance strategies that ensure optimum and equitable use of limited water resources. A well-governed resource ensures equity in the distribution of costs and benefits to its users (Wiek and Larson, 2012). When there is transparency and fairness in the allocation of tasks and benefits, users are more likely to see it as their responsibility to partake in maintaining resources. Active involvement of farmers in contributions towards the establishment and maintenance of their irrigation schemes is therefore recommended for the sustainability of smallholder irrigation schemes in Africa (Mutambara et al., 2016). Governance strategies that curtail free riding are crucial in this respect. Unlike private investments, where the investor is solely responsible for any future returns, the yields from putting effort into maintaining irrigation schemes (and CPRs in general) are dependent on the collective effort of all users. The governing strategies of WUAs may be assumed to influence the collective action of users, including their willingness to invest in maintenance, but to our knowledge, empirical research on this issue is missing so far.

Another factor that influences willingness to take part in maintenance activities is individual time preference. Devoting working time to maintenance is an investment with future returns. Users with less time preference (more patience) are more likely to invest in maintenance, other things being equal. People's level of time preference may be shaped by their past experiences. Holden et al. (1998) found that poverty in the past tends to create high rates of time preference. Although there is an increasing body of research on factors affecting time preferences, the role of time preference and its determinants in decisions regarding maintenance of small-scale irrigation systems has not yet been explored. This paper therefore examines two questions: (1) To what extent does a farmer's labour contribution to general irrigation maintenance depend on his or her perception of local governance performance and on his or her time preference? (2) What factors can explain time preferences in farmers? To answer these questions, we collected field data from small-scale irrigation farmers in northern Ghana.

The most common irrigation facilities in Ghana are small-scale reservoirs, mostly found in the Savannah Zone in the north. These schemes were constructed by the government with funding from development partners or by NGOs (Namara et al., 2011). Since their construction (or renovation), the daily management of the schemes has been handled by WUAs. The government is currently enrolling a policy in the agricultural sector to help fight poverty, dubbed "planting for food and jobs". The aim is to construct more dams in farming communities to boost agriculture. This study may help to identify aspects of WUAs' governance that need attention for achieving sustainable production, and thus provide support for the "planting for food and jobs" agenda. The results may also help improve WUAs' general operations and management of small-scale irrigation schemes.

The remaining sections of the paper is structured as follows. In the second section we present a conceptual framework of the relationships between poverty, time preferences, governance of irrigation resources, and maintenance of irrigation resources. The third section presents the research methodology. Discussion of results and final conclusions are outlined in the fourth and fifth sections respectively.

\section{CONCEPTUAL FRAMEWORK}

\section{Governing Irrigation Resources as Commons}

Common pool resources are resources characterized by rivalry in consumption and nonexclusiveness. Their open-access nature can lead to overuse of the resource by some individuals, thereby creating negative externalities for others in the short or long run (Birner et al., 2005; Ostrom and Gardner, 1993; Ostrom, 2000). In such cases, regulating its use and ensuring due diligence is encouraged. Without proper governance, small-scale irrigation schemes and other common pool resources are likely to suffer from the "tragedy of the commons" (GWP, 2009; Ostrom, 2000; Tortajada, 2010).

Following Herrera et al. (2014), we define irrigation governance as the rules and regulations that determine the use and management of irrigation resources by local users. Several dimensions of governance can be ascertained. While some rules encourage user participation in the operation and management of the facilities, others aim to ensure transparency, accountability, equity, sustainable 
management, and control of corruption (GWP, 2009; Lautze et al., 2011; Mansungu, 2004; Tortajada, 2010). In northern Ghana, Water User Associations (WUAs) are responsible for the general operation and maintenance of irrigation facilities, the allocation of land and water, and the collection of water fees (Mul et al., 2015; Namara et al., 2011; van Edig et al., 2003). Governance strategies of WUAs can have a major impact on the livelihoods of their members and communities at large. It is expected that good governance contributes to higher yields and lower poverty levels among irrigated-farm households.

Maintenance of irrigation facilities is important for irrigation sustenance and requires the participation of all users. The active involvement of users inculcates a sense of ownership, making them feel the need for sustainable management of irrigation resources (Mutambara et al., 2016). User involvement may however be influenced by the perceived style of governance. Outcomes from governing strategies may not satisfy all users equally and can affect the enthusiasm of users' participation in resource maintenance. Users who perceive governance as being good may likely contribute more labour towards maintenance. Though the perceived quality of governance may generally affect users' contributions, different dimensions of governance can have different effects on the willingness of users to contribute. Major maintenance activities of irrigation facilities in northern Ghana take place during the dry season (also called the irrigation season), the period in which rain-fed farming is not possible. The opportunity cost of participating in maintenance can be high because during this season farmers may engage in off-farm activities, such as trading, small-scale mining (galamsey) and artisanry, or may migrate to the south for menial jobs. Opportunity costs may differ between farmers due to their differences in education, social capital, and other factors driving off-farm employment and temporary migration.

\section{Time Preferences and Farmer Investments}

A person's rate of time preference measures the amount of future consumption he or she is willing to sacrifice for being able to consume one unit more in the present time. Becker and Mullingan (1997) described it as an index of the intertemporal marginal rate of substitution at all points in the current-future consumption plane. Persons with high rates of time preference are often impatient with respect to future benefits. Since time preference is a psychological disposition shaped by past experiences such as poverty, it may vary from person to person.

A farmer's willingness to invest is affected by his or her time preference. Time preference is an integral part of farmers' decisions regarding production activities including participation in conservation practices (Duquette et al., 2011; Shiferaw et al., 2009). In a study on time preferences of farm households in Ethiopia, Yesuf (2004) found that high time preferences significantly reduced adoption of soil conservation technologies. Similarly in Kenya, Duflo et al. (2011) found that impatient farmers failed to invest profitably in fertilizer purchases. For long-term investments Godoy et al. (1998) found that patient people find it more attractive to invest in clearing old-growth forests and wait for their returns. Hence, we may expect that the time preferences among water users will influence the amount of labour they are willing to invest for the maintenance of their irrigation scheme. Time preferences may be even more relevant than in the case of private investments because returns in public irrigation works generally show up later. Users with low time preferences may participate more in maintaining irrigation resources and may consequently contribute more labour to that effect.

A number of studies have tried to explain the level of time preferences among farmers. Holden et al. (1998) found that current liquidity as well as past wealth of households influenced rates of time preference. They showed that poor people were less likely to invest in environmental conservation. Recent studies provide support for the positive effect of poverty on time preferences. Living in a wealthy environment such as a household or village decreases one's time preference (Tanaka and Munro, 2012; Yesuf, 2004), as does higher wealth per capita (Wang et al., 2016). Access or proximity to economic factors such as good land and markets generally also decreases one's time preference (Holden et al., 1998). Tanaka and Munro (2012) found that individuals with more schooling are more patient in investing in community infrastructures. Education enlightens individuals on the benefits of investing to maintain group assets. Broadly, education can have any direction of effect on time preference. Yesuf (2004) explained that educated people may be forward- 
on the one hand, but may also have access to better investment opportunities, leading to high rates of time preference on the other. Probably, as stated by Becker and Mullingan (1997), "educated people should be more productive at reducing the remoteness of future pleasures".

Other personal characteristics such as age and gender of individuals are also found to influence time preferences (Becker and Mullingan, 1997; Wang et al., 2011; Yesuf, 2004). The effect of age is however ambiguous and can have any direction. Becker and Mullingan (1997) explained that young people tend to invest relatively much because they have more years remaining to harvest the returns, while older people invest less because fewer years remain. Children generally have short time horizons, which explains their impatience and unwillingness to invest. The future may therefore be discounted heavily at both young and old ages. In terms of sex, females are found to be more patient in investments (Silverman, 2003). Differences in time preference may also be explained by cultural differences and socioeconomic factors (Holden et al., 1998; Wang et al., 2016). The beliefs of people inform their perceptions and decisions. Investment decisions may thus be affected by cultural environment.

\section{Framework Used in This Study}

Figure 1 illustrates the relationships between governance, time preferences, and labour contributions to irrigation maintenance. In our framework, good governance perceptions might have a direct effect where it increases the expected returns to labour investment in maintenance by reducing free-rider problems. Governance strategies may not affect users equally, hence labour contributions to maintenance may not be equal. Labour contributions here refer to the number of man-days a household contributes towards maintenance activities.

FIGURE 1

TIME PREFERENCE AND GOVERNANCE PERCEPTION AS DETERMINANTS OF IRRIGATION MAINTENANCE

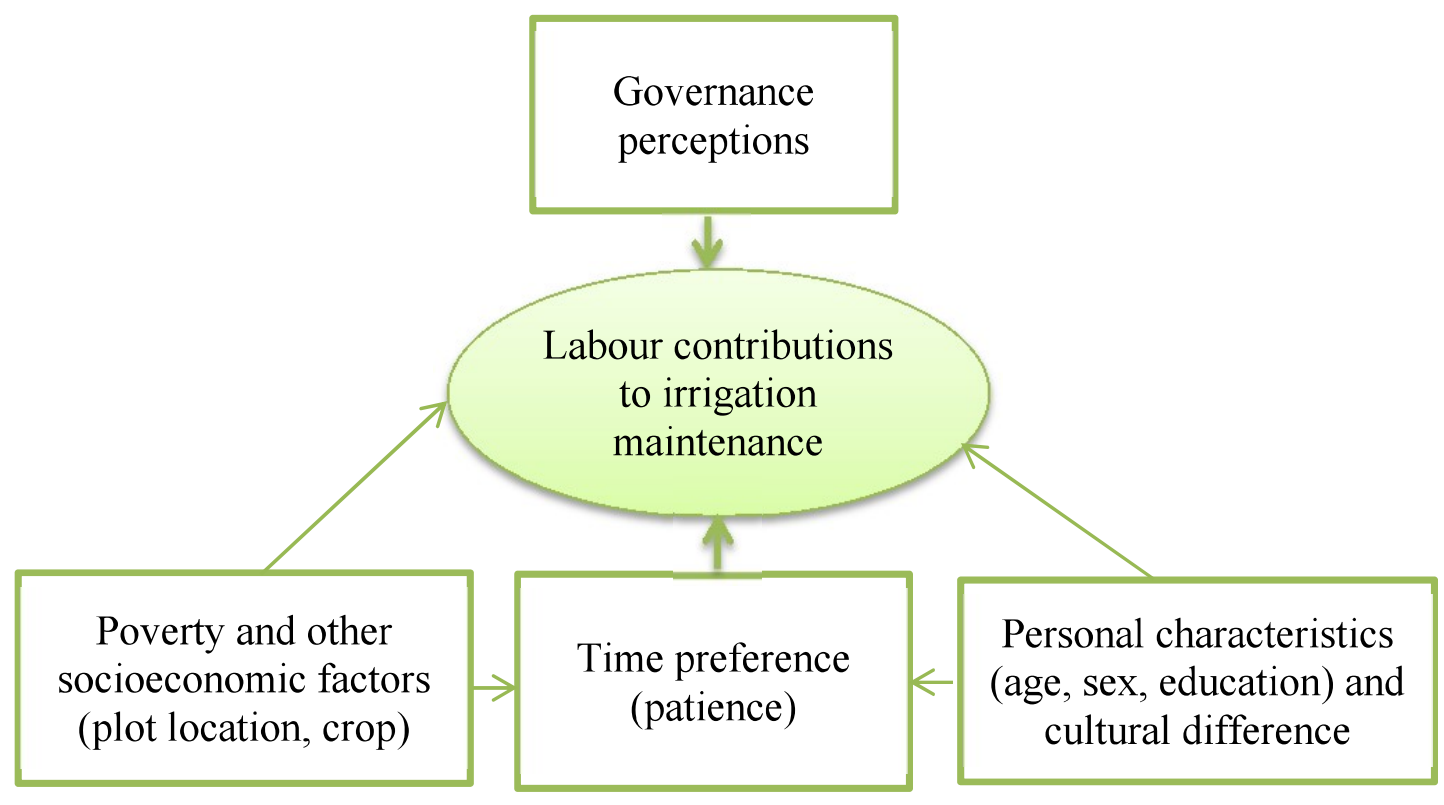

The individual contributions towards maintenance are a matter of choice even though key to the realisation of collective action. The benefits of contributing may not be realised immediately. Users who contribute more towards maintenance may therefore be those with much patience and enthusiasm for the sustainability of their scheme. Thus, time preference may influence a user's contribution to irrigation maintenance. 
Poverty is said to influence an individual's time preference. The patience to wait for the fruition of an investment is high when poverty is relatively low. For labour contribution, relatively poor users may prefer investing their time and effort into ventures that will bring instant returns as compared to investing in a common resource. We use the value of household farm lands and livestock as proxy for poverty. Other socioeconomic factors peculiar to irrigation are plot location and the crop grown. Plots at the tailends are often least preferred. Users located at these ends may be termed as resource-poor. Resource-poor farmers mostly have short planning horizons and thus face difficulties in adopting a long-term view (Holden et al. 1998).

Several factors affect a scheme's choice for a particular crop. These may include history of diseases, water challenges, and relative output and input prices for various crops. The main crop grown in a scheme may therefore also affect one's time preference, because "if farmers are able to recognize indirect costs, they will be factored into their consideration of investment strategies" (Shiferaw et al., 2009). Personal characteristics such as number of years in formal education, and age and sex of water users may also influence time preference. The study area has many ethnic groups with varied cultural practices. The regions in which schemes, and thus users, are located may therefore influence time preference.

\section{METHODOLOGY}

\section{Data Collection}

Data from a household survey of 18 smallholder irrigation schemes in northern Ghana (Northern, Upper East, and Upper West Regions) was used. This part of the country is relatively dry and has a short rainy season stretching from May to August. Annual rainfall is an average of $1000 \mathrm{~mm}$ and only one cropping season exists. Dry season irrigation of different types is practiced by communities with water bodies to complement rain fed harvests. The predominant type of irrigation is surface water irrigation from small reservoirs constructed by government and donor organizations. Irrigated crops are mainly rice and vegetables including tomatoes, onions, pepper, and leafy vegetables.

This data was complemented with a field experiment to estimate time preferences of irrigators. A simple random approach using the lottery method was used to sample ten (10) respondents from each WUA of the 18 schemes, giving a total of 180 participants in both the survey and experiment. Labour contributions towards maintenance were measured in terms of man-days (each man-day being equivalent to six hours of labour). Irrigation plots are household assets but there is always one household member using the plot or leading in decisions regarding farming on the plot. Respondents in this study are the main farmers (using the household irrigation plots). For each scheme, one of the three crops considered dominant in the scheme was chosen. Only users who did grow the dominant crop took part in the sampling process. Non-growers of these crops were however allowed to take part in focus group discussions.

We incorporated 46 indicators of irrigation governance, segregated into six dimensions of governance in the household questionnaire for users to assess using a 5-point Likert scale. The dimensions included participation, accountability, conflict management, transparency and cooperation, equity and fairness, and sustainable use. Indicators were put in the form of positive statements and respondents asked to indicate their opinions on a scale from 1 indicating "strongly disagree" to 5 meaning "strongly agree". Likert-type items grouped into survey scales is recommended in cases where a single survey item is insufficient in capturing a construct (Gliem and Gliem, 2003; Sullivan and Artino Jr, 2013). Parametric analysis is possible using mean or total scores if the scale passes Cronbach alpha test of internal consistency (Sullivan and Artino Jr, 2013).

\section{Estimating Time Preferences}

Two main approaches have been used to estimate time preferences in the past: through consumption data, where discount rates are inferred from real-life decisions (Cagetti, 2003; Dreyfus and Viscusi, 1995; Hausman, 1979), and through experimental data (Andersen et al., 2008; Frederick et al., 2002; Tanaka et al., 2010). Recently, experiments have been the favoured approach, with multiple price list (MPL) 
methods being the most commonly used (Andersen et al., 2008; Andreoni and Sprenger, 2012; Tanaka et al., 2010). The MPL method employs multiple questions asked to individuals to choose between smaller payments closer to the present, and relatively larger payments in the future, with interest rates increasing monotonically in a price list. Discount rates using standard methods like MPL are however said to be upward-biased, and thus too high on average, due to the linear preferences in their design (Andreoni et al., 2013; Andreoni and Sprenger, 2012). To minimize this, Andreoni and Sprenger $(2010,2012)$ proposed the so-called Convex Time Budget (CTB) method. The advantage of the CTB method over standard elicitation methods is its ability to identify discounting and utility function curvature (risk aversion) and its ability to test for present biases, at both the individual and aggregate level (Ibid). Following Andreoni and Sprenger (2012), we used a CTB design in estimating time preferences of irrigators. Appendix 1 describes the experimental design and estimation results.

\section{Empirical Approach}

We estimate two relationships. First, labour contributions to maintenance $(L C)$ are considered to be a function of governance perceptions $(G P)$, time preference $(T P)$, and other factors $(O F)$ :

$L C_{i j}=f\left(G P_{i j}, T P_{i j}, O F_{i j}\right)+e_{i j} \quad$ for $i=1, \ldots, 180, j=1, \ldots, 18$

where:

$L C_{i j} \quad=$ Household labour contribution by user $i$ in scheme $j$

$G P_{i j} \quad=$ Governance perceptions of user $i$ in scheme $j$

$T P_{i j} \quad=$ Time preference of user $i$ in scheme $j$

$O F_{i j} \quad=$ Other factors of user $i$ in scheme $j$

$e_{i j} \quad=$ Error term

Second, time preference rates of users $(T P)$ are thought to be a function of wealth $(W)$, socioeconomic properties of a scheme $(S F)$, such as plot size, group size, age of the scheme, plot location and crop grown, personal characteristics $(P C)$, including age, sex, education and household labour force, and cultural background $(C B)$ :

$T P_{i j}=g\left(W_{i j}, S F_{i j}, P C_{i j}, C B_{i j}\right)+u_{i j} \quad$ for $i=1, \ldots, 180, j=1, \ldots, 18$

where

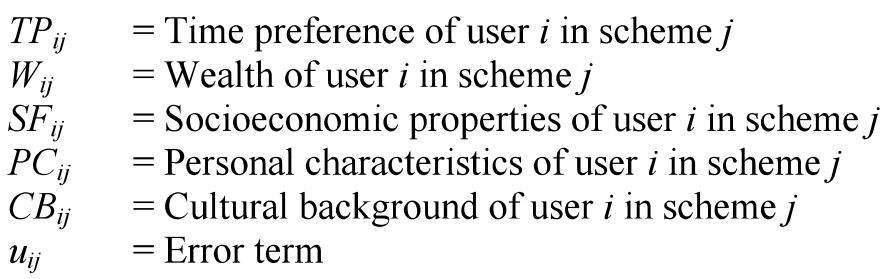

Equation (1) is estimated using a Tobit approach while equation (2) is estimated with Ordinary Least Squares (OLS). We used Tobit because a linear model would ignore the zero lower bound and not take into account that a user may not participate in maintenance activities. The Tobit approach does take this into account and therefore improves standard linear estimates. We also employ Generalized Linear Model (GLM) and OLS regressions to test the robustness of the results. The GLM method is able to estimate regressions with arbitrary and/or skewed continuous distributions in a consistent manner compared to standard methods like OLS (McCulloch, 2000). Because the error terms may be correlated for households living within the same irrigation scheme, we apply the "Robust-Clustered" errors approach (at scheme level) in both estimation procedures. 
Table 1 presents definitions of the variables used in the regression equations and the signs of their expected influence. In addition to the effects of governance and time preferences, which have been described in our framework above, many other factors can influence labour contributions and time preferences as indicated in Table 1.

TABLE 1

DEFINITION OF VARIABLES AND EXPECTED INFLUENCE

\begin{tabular}{|c|c|c|c|}
\hline Variable & Definition & Labour & $\begin{array}{l}\text { Time } \\
\text { pref. }\end{array}$ \\
\hline \multicolumn{4}{|c|}{ Dependent variables } \\
\hline $\begin{array}{l}\text { Labour } \\
\text { contribution }\end{array}$ & $\begin{array}{l}\text { Number of days a user household took part in maintenance } \\
\text { activities of public spaces not directly bordering the household's } \\
\text { plot in the past year }\end{array}$ & & \\
\hline Time preference & $\begin{array}{l}\text { Daily time preference rate }(=\text { inverse of daily discount rate, minus } \\
\text { one) obtained from Convex Time Budget }(\mathrm{CTB}) \text { experiment }\end{array}$ & - & \\
\hline \multicolumn{4}{|c|}{ Governance perceptions } \\
\hline Participation & Mean rank of participation indicators in a 1-to-5 Likert scale & + & \\
\hline Accountability & Mean rank of accountability indicators in a 1-to-5 Likert scale & + & \\
\hline $\begin{array}{l}\text { Conflict } \\
\text { management }\end{array}$ & $\begin{array}{l}\text { Mean rank of conflict management indicators in a 1-to-5 Likert } \\
\text { scale }\end{array}$ & + & \\
\hline $\begin{array}{l}\text { Transparency and } \\
\text { cooperation }\end{array}$ & $\begin{array}{l}\text { Mean rank of transparency and cooperation indicators in a 1-to-5 } \\
\text { Likert scale }\end{array}$ & + & \\
\hline Equity and fairness & Mean rank of equity and fairness indicators in a 1-to-5 Likert scale & + & \\
\hline Sustainable use & Mean rank of sustainable use indicators in a 1-to-5 Likert scale & + & \\
\hline $\begin{array}{l}\text { Overall governance } \\
\text { perception }\end{array}$ & $\begin{array}{l}\text { Mean rank of all governance dimensions in a 1-to-5 Likert scale, } \\
\text { with all dimensions having equal weight }\end{array}$ & + & \\
\hline \multicolumn{4}{|c|}{ Other factors } \\
\hline \multicolumn{4}{|l|}{ Wealth } \\
\hline Household wealth & $\begin{array}{l}\text { Value of household farm lands and livestock in Ghana Cedis } \\
\text { (expressed in GHC '000) }\end{array}$ & & - \\
\hline Wealth per capita & $\begin{array}{l}\text { Household wealth per person in Ghana Cedis (expressed in GHC } \\
\text { '000) }\end{array}$ & & - \\
\hline \multicolumn{4}{|c|}{ Socioeconomic properties } \\
\hline Plot size & Size of plot allocated to a household in acres & + & \\
\hline Group size & Number of users in a WUA & - & + \\
\hline Age of scheme & The number of years a scheme has existed & $-/+$ & $-1+$ \\
\hline Head-end plot & A dummy that takes a value of 1 if plot location is at head-end & - & - \\
\hline Tail-end plot & A dummy that takes a value of 1 if plot location is at tail-end & + & + \\
\hline Tomatoes & A dummy that takes a value of 1 if main crop is tomatoes & $-/+$ & $-/+$ \\
\hline Onions & A dummy that takes a value of 1 if main crop is onions & $-/+$ & $-/+$ \\
\hline \multicolumn{4}{|c|}{ Personal characteristics } \\
\hline Age & Age of user in years & + & - \\
\hline Sex & A dummy that takes a value of 1 if the user is male & + & $-/+$ \\
\hline Educational level & $\begin{array}{l}\text { Number of years of formal education (also an indicator of } \\
\text { opportunity cost) }\end{array}$ & $-1+$ & $-/+$ \\
\hline $\begin{array}{l}\text { Household labour } \\
\text { force }\end{array}$ & Number of people in the household that are 15 years or older & + & \\
\hline \multicolumn{4}{|l|}{ Cultural background } \\
\hline Upper East Region & A dummy that takes a value of 1 if region is Upper East & $-/+$ & $-1+$ \\
\hline Upper West Region & A dummy that takes a value of 1 if region is Upper West & $-1+$ & $-1+$ \\
\hline
\end{tabular}




\section{RESULTS AND DISCUSSION}

\section{Summary Statistics}

In Table 2, we present the summary statistics of variables included in our analysis for 107 observations out of the 180 sampled participants. Time preferences could be estimated for 107 subjects only. Of the remaining 73 subjects, 52 subjects switched multiple times, while 21 subjects had no variation in their choices. This may be due to subject confusion following the elaborate nature of the CTB design.

TABLE 2

SUMMARY STATISTICS, 107 OBSERVATIONS

\begin{tabular}{|c|c|c|c|c|c|}
\hline Variable & Mean & StdDev. & Min & Max & $\mathrm{CV}$ \\
\hline \multicolumn{6}{|c|}{ Dependent variables } \\
\hline Labour contribution (days) & 2.477 & 1.679 & 0 & 8 & 0.678 \\
\hline Daily discount factor & 0.984 & 0.018 & 0.890 & 1.012 & 0.018 \\
\hline Daily time preference rate & 0.017 & 0.0194 & -0.012 & 0.123 & 1.141 \\
\hline \multicolumn{6}{|c|}{ Governance perceptions } \\
\hline Overall gov. perception & 3.836 & 0.459 & 1.681 & 4.560 & 0.120 \\
\hline Participation & 4.062 & 0.472 & 2.8 & 5 & 0.116 \\
\hline Accountability & 3.660 & 0.762 & 1.2 & 4.8 & 0.208 \\
\hline Conflict management & 4.287 & 0.615 & 1 & 5 & 0.143 \\
\hline Transparency and cooperation & 3.860 & 0.686 & 1.067 & 4.933333 & 0.178 \\
\hline Equity and fairness & 3.650 & 0.563 & 2 & 4.857 & 0.154 \\
\hline Sustainable use & 3.494 & 0.533 & 1.818 & 4.545 & 0.153 \\
\hline \multicolumn{6}{|c|}{ Other factors } \\
\hline \multicolumn{6}{|l|}{ Wealth } \\
\hline $\begin{array}{l}\text { Household wealth (1000 } \\
\text { GHC) }\end{array}$ & 9.170 & 5.723 & 1.750 & 27.775 & 0.624 \\
\hline Wealth per capita (1000 GHC) & 1.393 & 0.965 & 0.165 & 5.265 & 0.693 \\
\hline \multicolumn{6}{|l|}{ Socioeconomic properties } \\
\hline Plot size (acres) & 0.226 & 0.142 & 0.056 & 0.5 & 0.628 \\
\hline Group size & 71.561 & 34.182 & 17 & 125 & 0.478 \\
\hline Age of scheme (years) & 44.523 & 18.248 & 16 & 81 & 0.410 \\
\hline Head-end plot & 0.271 & 0.447 & 0 & 1 & 1.649 \\
\hline Tail-end plot & 0.234 & 0.425 & 0 & 1 & 1.816 \\
\hline Tomatoes & 0.299 & 0.460 & 0 & 1 & 1.538 \\
\hline Onions & 0.364 & 0.484 & 0 & 1 & 1.330 \\
\hline \multicolumn{6}{|l|}{ Personal characteristics } \\
\hline Age (years) & 43.607 & 12.119 & 18 & 85 & 0.278 \\
\hline Sex $($ male $=1)$ & 0.626 & 0.486 & 0 & 1 & 0.776 \\
\hline Education (years) & 3.776 & 4.853 & 0 & 16 & 1.285 \\
\hline Household labour force & 7.262 & 2.575 & 3 & 15 & 0.355 \\
\hline \multicolumn{6}{|l|}{ Cultural background } \\
\hline Upper East Region & 0.692 & 0.464 & 0 & 1 & 0.671 \\
\hline Upper West Region & 0.028 & 0.166 & 0 & 1 & 5.929 \\
\hline
\end{tabular}

An attrition check using a Probit regression (see Appendix 3) indicates that the probability of a participant being included in the 107 observations sample is significantly influenced by household wealth 
(1000 GHC) and mobility (= number of times the irrigator migrated last season), whereas age, sex, education and religion do not play a significant role. The negative estimated coefficient for wealth may be explained by the fact that small changes in income are much less important for wealthier persons than they are for poorer persons. Hence, the amount of money used for playing the game has a different meaning for them. Less wealthy farmers are more likely to take the game serious. On the other hand farmers who frequently migrated during the previous season are more likely to be involved in the market economy than those who remain at home. They are probably more aware of the value of money as compared to (semi-subsistence) farmers. These results suggest that the sample of 107 observations is not just a random sub-sample of the 180 irrigators who played the game, and that the results that we obtain in this chapter apply in particular to those irrigators who have relatively low wealth and more migration experience. Inconsistent choices is a common problem in standard multiple price list experiments. Depending on the subject pool, about $10-75 \%$ of the subjects make inconsistent choices (Charness and Viceisza, 2011; Meier and Sprenger, 2010; Jacobson and Petrie, 2009). This is assumed to be slightly lower with the CTB approach (Andreoni and Sprenger, 2012, p 3345).

The mean contribution of labour to irrigation maintenance is 2.5 days, with a minimum of zero days and a maximum of 8 days. Daily discount factors of users range between 0.89 and 1.012. The mean discount factor is 0.984 , while the median equals 0.988 . The estimated median is lower than the one estimated for American university students by Andreoni and Sprenger (2012), who obtained a median estimate of 0.9991 . The mean daily time preference rate is $1.7 \%$ with minimum and maximum of about $1.2 \%$ and $12.3 \%$ respectively, while the median daily time preference rate is $1.2 \%$. In the experiment of Andreoni and Sprenger (2012), the estimated median daily time preference rate equals $0.09 \%$. The relatively high time preferences estimated from our experiment may not only reflect differences in wealth between American university students and Ghanaian smallholders (see also regression results for wealth in time preferences equation presented below), but also from the fact that the CTB experiment estimates nominal instead of real time preferences. Year-on-year inflation in Ghana stood at ca. 17 percent during the months when we carried out the experiments (November 2014 - April 2015). The interest rates that we used in the CTB experiment reflect the rapid price increases and corresponding depreciation of the Ghanaian Cedi (see Appendix 1).

The mean overall governance perception is 3.8 , with a minimum of 1.7 and a maximum of 4.6 . The mean rating is fairly above the average (3), indicating a relatively positive perceived governance in the study area. The coefficient of variation $(\mathrm{CV})$ is 0.12 , indicating that the variation in perceptions is relatively small compared to its mean value. The lowest ranked governance dimension is sustainable use, with a mean value of 3.5. Conflict management had the highest mean of 4.3 , and is thus perceived as relatively good, while sustainable use is considered problematic. The other four governance dimensions have mean values ranging between 3.7 and 4.1, and hence are perceived as positive on average by the scheme users. Accountability perceptions has the highest coefficient of variation (0.21), implying that there is relatively much variation in the opinions about this dimension compared to the other governance dimensions. The correlation coefficients among the governance dimensions, presented in Table 3, show that they are not very large except for the correlation between accountability and transparency and cooperation (which equals 0.82 ).

Table 2 further indicates that household wealth status of respondents varied from a low of 1.75 to a high of 27.78 thousand Ghana Cedis worth of farmlands and livestock. The mean wealth is 9.17, with a standard deviation of 5.72 thousand Ghana Cedis and a coefficient of variation of $62 \%$. The variation is even wider when wealth per capita is considered. The mean wealth per capita in a household is about 1.39 thousand Ghana Cedis with 0.17 and 5.27 thousand Ghana Cedis as minimum and maximum wealth per capita respectively. The standard deviation of wealth per capita is $69 \%$ of the mean.

Plots allocated to households by management range from 0.056 to 0.5 acres with a mean size of 0.229 acres. The standard deviation of plot size is 0.142 . Several factors are considered during the allocation of plots to households including proportion of the household's farm land that was confiscated or destroyed in the process of constructing reservoirs which may explain the variability in plot sizes. The irrigation schemes have a mean user group size of 72 farmers, with the smallest user group size being 17 farmers 
and the largest group size 125 farmers. The mean age of these schemes is 45 years, the minimum is 16 years and the maximum is 81 years. About $27 \%$ and $23 \%$ of respondents were allocated head-end and tail-end plots, respectively. Hence, $50 \%$ of the farmers have plots located in the middle of the scheme. The sampled crops (tomatoes, onions, pepper) had about 30\%, 36\% and 34\% respective representation in the respondents.

TABLE 3

CORRELATION COEFFICIENTS AMONG GOVERNANCE DIMENSIONS

\begin{tabular}{|l|l|l|l|l|l|l|}
\hline & Participation & Accountability & $\begin{array}{l}\text { Conflict } \\
\text { management }\end{array}$ & $\begin{array}{l}\text { Transparency } \\
\text { and } \\
\text { cooperation }\end{array}$ & $\begin{array}{l}\text { Fairness and } \\
\text { equity }\end{array}$ & $\begin{array}{l}\text { Sustainable } \\
\text { use }\end{array}$ \\
\hline Participation & 1 & & & & & \\
\hline Accountability & 0.5592 & 1 & & & & \\
\hline $\begin{array}{l}\text { Conflict } \\
\text { management }\end{array}$ & 0.4338 & 0.6635 & 1 & & & \\
\hline $\begin{array}{l}\text { Transparency } \\
\text { and } \\
\text { cooperation }\end{array}$ & 0.5814 & 0.8231 & 0.6121 & 1 & & \\
\hline $\begin{array}{l}\text { Fairness and } \\
\text { equity }\end{array}$ & 0.5385 & 0.5541 & 0.4850 & 0.6626 & 1 & \\
\hline Sustainable use & 0.1054 & 0.0858 & 0.2975 & 0.1757 & 0.4151 & 1 \\
\hline
\end{tabular}

Most of the respondents were middle-aged with a mean age of 43.6 years. The minimum age recorded is 18 years and the maximum 85 years. The sample had about $63 \%$ males and $37 \%$ females. Farming in northern Ghana is generally male-dominated, which is reflected in our study sample. Farmers on average spent 3.8 years on formal education. While some spent up to 16 years on schooling, some farmers did not have any level of formal education. The mean household labour force size is 7.26 with a minimum of 3 persons and a maximum of 15 . In terms of location, about $69 \%$ of respondents are from the Upper East Region, 3\% from the Upper West Region and 28\% from the Northern Region. Most small-scale irrigation facilities are located in the Upper East Region.

\section{Regression Results}

\section{Labour Contributions to Maintenance}

Table 4 presents results of our regression analysis for labour contributions to maintenance using a Tobit approach. The first regression (column 1) estimates determinants of labour contributions using overall governance perception as one of the explanatory variables, and column 2 presents the estimation results when governance is split into its six dimensions. The table also presents estimates when only significant governance dimensions are considered (column (3)) and when seemingly correlated dimensions (accountability and transparency and cooperation as indicated in Table 3 ) are iterated with the two significant dimensions (columns (4) and (5)). The estimated relation of the overall governance perception to labour contributions is positive and highly significant. An increase of one unit in governance perception (on a 1-5 scale) relates to about 1.1 increase in the expected number of labour days contributed towards maintenance. 
TABLE 4

TOBIT REGRESSION RESULTS FOR LABOUR CONTRIBUTIONS

\begin{tabular}{|c|c|c|c|c|c|}
\hline Variables & (1) & $(2)$ & (3) & (4) & $(5)$ \\
\hline $\begin{array}{l}\text { Overall gov. } \\
\text { Perception }\end{array}$ & $\begin{array}{l}1.100 * * * \\
(0.357)\end{array}$ & & & & \\
\hline Participation & & $\begin{array}{l}0.011 \\
(0.354)\end{array}$ & & & \\
\hline Accountability & & $\begin{array}{l}0.102 \\
(0.344)\end{array}$ & & $\begin{array}{l}0.307 \\
(0.273)\end{array}$ & \\
\hline $\begin{array}{l}\text { Conflict } \\
\text { Management }\end{array}$ & & $\begin{array}{l}0.785^{* *} \\
(0.366)\end{array}$ & $\begin{array}{l}1.043 * * * \\
(0.298)\end{array}$ & $\begin{array}{l}0.853^{* *} \\
(0.364)\end{array}$ & $\begin{array}{l}0.872 * * \\
(0.341) \\
\end{array}$ \\
\hline $\begin{array}{l}\text { Transparency and } \\
\text { Cooperation }\end{array}$ & & $\begin{array}{l}0.392 \\
(0.428)\end{array}$ & & & $\begin{array}{l}0.433 \\
(0.345)\end{array}$ \\
\hline Equity and fairness & & $\begin{array}{l}0.709^{* *} \\
(0.269)\end{array}$ & $\begin{array}{l}0.427^{* *} \\
(0.203)\end{array}$ & $\begin{array}{l}0.460^{* *} \\
(0.206)\end{array}$ & $\begin{array}{l}0.579 * * \\
(0.237)\end{array}$ \\
\hline Sustainable use & & $\begin{array}{l}0.263 \\
(0.268)\end{array}$ & & & \\
\hline $\begin{array}{l}\text { Daily time } \\
\text { Preference }\end{array}$ & $\begin{array}{l}-4.045 \\
(4.641)\end{array}$ & $\begin{array}{l}-4.947 \\
(4.745)\end{array}$ & $\begin{array}{l}-3.567 \\
(5.046)\end{array}$ & $\begin{array}{l}-3.984 \\
(4.852)\end{array}$ & $\begin{array}{l}-4.094 \\
(5.006)\end{array}$ \\
\hline Age & $\begin{array}{l}-0.021 * * \\
(0.009)\end{array}$ & $\begin{array}{l}-0.024^{* *} \\
(0.009)\end{array}$ & $\begin{array}{l}-0.024 * * \\
(0.009)\end{array}$ & $\begin{array}{l}-0.024 * * * \\
(0.009)\end{array}$ & $\begin{array}{l}-0.025 * * * \\
(0.009)\end{array}$ \\
\hline Sex & $\begin{array}{l}-0.333 \\
(0.223)\end{array}$ & $\begin{array}{l}-0.329 \\
(0.224) \\
\end{array}$ & $\begin{array}{l}-0.289 \\
(0.221) \\
\end{array}$ & $\begin{array}{l}-0.303 \\
(0.214)\end{array}$ & $\begin{array}{l}-0.350 \\
(0.231)\end{array}$ \\
\hline Education & $\begin{array}{l}-0.074 * * * \\
(0.022)\end{array}$ & $\begin{array}{l}-0.076^{* * *} \\
(0.021)\end{array}$ & $\begin{array}{l}-0.081 * * * \\
(0.023)\end{array}$ & $\begin{array}{l}-0.079 * * * \\
(0.023)\end{array}$ & $\begin{array}{l}-0.077 * * * \\
(0.022)\end{array}$ \\
\hline $\begin{array}{l}\text { Household labour } \\
\text { Force }\end{array}$ & $\begin{array}{l}-0.008 \\
(0.051)\end{array}$ & $\begin{array}{l}0.002 \\
(0.060)\end{array}$ & $\begin{array}{l}-0.008 \\
(0.053)\end{array}$ & $\begin{array}{l}-0.003 \\
(0.055)\end{array}$ & $\begin{array}{l}-0.011 \\
(0.052)\end{array}$ \\
\hline Plot size & $\begin{array}{l}1.696 \\
(1.054)\end{array}$ & $\begin{array}{l}1.938^{*} \\
(1.016)\end{array}$ & $\begin{array}{l}2.003^{* *} \\
(0.839)\end{array}$ & $\begin{array}{l}1.979 * * \\
(0.894)\end{array}$ & $\begin{array}{l}1.716^{*} \\
(0.889)\end{array}$ \\
\hline Group size & $\begin{array}{l}0.005 \\
(0.005)\end{array}$ & $\begin{array}{l}0.007 \\
(0.005)\end{array}$ & $\begin{array}{l}0.007 \\
(0.005) \\
\end{array}$ & $\begin{array}{l}0.007 \\
(0.005) \\
\end{array}$ & $\begin{array}{l}0.008 \\
(0.005) \\
\end{array}$ \\
\hline Age of scheme & $\begin{array}{l}0.011^{*} \\
(0.007)\end{array}$ & $\begin{array}{l}0.007 \\
(0.007)\end{array}$ & $\begin{array}{l}0.009 \\
(0.006)\end{array}$ & $\begin{array}{l}0.008 \\
(0.007)\end{array}$ & $\begin{array}{l}0.006 \\
(0.008)\end{array}$ \\
\hline Head-end plot & $\begin{array}{l}-1.324 * * * \\
(0.281)\end{array}$ & $\begin{array}{l}-1.260^{* * *} \\
(0.224)\end{array}$ & $\begin{array}{l}-1.400^{* * * *} \\
(0.250)\end{array}$ & $\begin{array}{l}-1.380 * * * \\
(0.228)\end{array}$ & $\begin{array}{l}-1.325 * * * \\
(0.235)\end{array}$ \\
\hline Tail-end plot & $\begin{array}{l}0.120 \\
(0.367)\end{array}$ & $\begin{array}{l}0.087 \\
(0.361)\end{array}$ & $\begin{array}{l}0.106 \\
(0.379)\end{array}$ & $\begin{array}{l}0.079 \\
(0.376)\end{array}$ & $\begin{array}{l}0.051 \\
(0.358) \\
\end{array}$ \\
\hline Tomatoes & $\begin{array}{l}1.994^{* * * *} \\
(0.259)\end{array}$ & $\begin{array}{l}2.102 * * * \\
(0.245)\end{array}$ & $\begin{array}{l}2.156^{* * *} \\
(0.215)\end{array}$ & $\begin{array}{l}2.062 * * * \\
(0.247)\end{array}$ & $\begin{array}{l}2.101^{* * *} \\
(0.234)\end{array}$ \\
\hline Onions & $\begin{array}{l}1.313^{* * * *} \\
(0.319)\end{array}$ & $\begin{array}{l}1.315^{* * * *} \\
(0.353)\end{array}$ & $\begin{array}{l}1.213^{* * * *} \\
(0.284)\end{array}$ & $\begin{array}{l}1.129 * * * \\
(0.322)\end{array}$ & $\begin{array}{l}1.282 * * * \\
(0.283)\end{array}$ \\
\hline Upper East & $\begin{array}{l}-1.368^{* * *} \\
(0.293)\end{array}$ & $\begin{array}{l}-1.015^{* * *} \\
(0.313)\end{array}$ & $\begin{array}{l}-0.879^{* * *} \\
(0.213)\end{array}$ & $\begin{array}{l}-1.052^{* * * *} \\
(0.254)\end{array}$ & $\begin{array}{l}-1.091^{* * * *} \\
(0.258)\end{array}$ \\
\hline Upper West & $\begin{array}{l}0.969 * * \\
(0.473)\end{array}$ & $\begin{array}{l}1.427 * * * \\
(0.501)\end{array}$ & $\begin{array}{l}1.804 * * * \\
(0.287)\end{array}$ & $\begin{array}{l}1.410 * * * \\
(0.505)\end{array}$ & $\begin{array}{l}1.449 * * * \\
(0.456)\end{array}$ \\
\hline Constant & $\begin{array}{l}-1.297 \\
(1.377) \\
\end{array}$ & $\begin{array}{l}-5.210^{*} \\
(2.717) \\
\end{array}$ & $\begin{array}{l}-2.916 \\
(1.799) \\
\end{array}$ & $\begin{array}{l}-3.093 \\
(1.917)\end{array}$ & $\begin{array}{l}-3.837^{*} \\
(2.0250 \\
\end{array}$ \\
\hline Observations & 107 & 107 & 107 & 107 & 107 \\
\hline Pseudo R-squared & 0.1517 & 0.1801 & 0.1739 & 0.1579 & 0.1527 \\
\hline
\end{tabular}

Notes: ${ }^{* *} \mathrm{p}<0.01,{ }^{* *} \mathrm{p}<0.05,{ }^{*} \mathrm{p}<0.1$; Cluster robust standard errors in parentheses 
The results presented in the second column suggest that perceptions about conflict management and equity and fairness are the governance dimensions that are of most importance to the sampled farmers. An increase of one unit in conflict management perceptions associates with an increase in expected labour contribution by 0.79 days, while a similar increase in perceptions on equity and fairness increases the expected contribution by 0.71 days. The significant associations of conflict management and equity and fairness with labour contribution can be related to the fact that most people like to associate with the best in terms of serenity and respect for rights. Investments stride well in peaceful environments where obstructions are less. Equity and fairness is an assurance that returns from investments will not be infringed upon. Farmers are motivated by these which explains the significant relations of these variables to labour contributions.

The estimated coefficient for perceptions of conflict management becomes even more significant when included in the equation with equity and fairness as the only governance dimensions (column (3)). The insignificance of other governance dimensions may be affected by collinearity among those dimensions, and therefore should be interpreted with care. In columns (4) and (5) we present the regressions results when conflict management and equity and fairness are both combined with accountability and transparency and cooperation respectively. As can be seen from the results, the estimated coefficients for the seemingly correlated dimensions (accountability and transparency and cooperation) are still not significantly different from zero. This means that conflict management and equity and fairness are the governance dimensions that play significant roles in labour contributions to irrigation maintenance in this sample. The results further provide some evidence that time preference has a negative association with labour contributions, as we posited. However, the estimated coefficient is not significantly different from zero.

Other factors that are significantly related to labour contributions to irrigation maintenance include age, education, plot size, plot location, main crop, and regional difference. An increase in the age of a farmer by a year decreases his expected labour contributions by 0.024 labour days. An additional year of formal education of a farmer decreases his expected labour contributions by 0.076 labour days. Plot size has a significant positive relationship with labour contributions. A 0.1 acre increase in the land allocated to a household is associated with a 0.194 days increase in the expected contributions to maintenance. Households with large irrigated plots have the advantage of gaining more when the resource is wellmaintained

As we expected, plot location relates to the amount of labour a farmer contributes to maintenance. The influence of being allocated a head-end plot is negative and significant, which is consistent with findings in Nagrah et al. (2016). The associated influence of having a tail-end plot is not significantly different from zero. The estimated coefficient for the head-end dummy indicates that, controlling for other factors, farmers with plots at the head-end are expected to contribute on average 1.26 labour days less than farmers with plots in the middle.

The dominant crop grown in a scheme is also found to have a significant relation to maintenance contributions. Tomato farmers are expected to contribute on average 2.1 days more than pepper farmers, and onion farmers 1.32 days more (when other factors affecting labour contributions are controlled). The regional differences of farmers also influence their labour contributions. Farmers located in the Upper East Region are expected to contribute on average 1.02 labour days less than farmers in the Northern Region while farmers in the Upper West Region are expected to contribute 1.43 labour days more than those in the Northern Region. Variabilities in the regions such as culture, temperatures, and alternative livelihood activities among others may account for this. Poverty is more pronounced in the Upper East Region. Farmers tin the region involve in different economic activities at a time thereby dividing their labour days among the lot. This may explain why farmers in the Upper East Region contribute less labour than farmers in the Northern Region.

Additionally, we estimated the same two equations by OLS and GLM as robustness checks. The results are presented in Appendix 2. The main conclusions that can be derived from these results are similar to the ones we drew from the Tobit regression results. 


\section{Time Preferences}

In Table 5, we present the OLS regression results for the daily time preference rates. Two different equations were estimated, one with total household wealth (column 1) and one with per capita wealth (column 2) among the explanatory variables.

The relationship between wealth and time preference is negative, as expected. However, only household wealth is found to have a statistically significant relation; the estimated coefficient for per capita wealth does not differ significantly from zero. A GHC 1,000 increase in the wealth of a farm household is associated with a 0.1 percentage points decline in a user's daily time preference rate. This finding is consistent with Tanaka and Munro (2012), and Yesuf (2004), who found that household wealth correlates with low rates of time preferences and thus patience. It may be that poor households are concerned about the present needs of their families due to inadequacies and will therefore be too impatient to plan long-term investments. Relatively wealthy farmers can sell or rent out part of their assets when the need arises and therefore have lower time preferences. But the estimated relationship may also reflect that households with low time preferences tend to accumulate more wealth.

TABLE 5

OLS REGRESSION RESULTS FOR DAILY TIME PREFERENCE RATES

\begin{tabular}{|l|l|l|}
\hline Variable & $(1)$ & $(2)$ \\
\hline Household wealth & $-0.001^{* * *}$ & \\
& $(0.000)$ & \\
\hline Wealth per capita & & -0.002 \\
& & $(0.002)$ \\
\hline Group size & -0.000 & -0.000 \\
& $(0.000)$ & $(0.000)$ \\
\hline Age of scheme & 0.000 & -0.000 \\
& $(0.000)$ & $(0.000)$ \\
\hline Head-end plot & $0.008^{*}$ & $0.009^{* *}$ \\
& $(0.004)$ & $(0.004)$ \\
\hline Tail-end plot & 0.000 & 0.001 \\
& $(0.005)$ & $(0.005)$ \\
\hline Tomatoes & $0.010^{* * *}$ & $0.011^{* * *}$ \\
& $(0.002)$ & $(0.003)$ \\
\hline Onions & $0.017^{* * *}$ & $0.017^{* * *}$ \\
& $(0.005)$ & $(0.005)$ \\
\hline Age & 0.000 & 0.000 \\
& $(0.000)$ & $(0.000)$ \\
\hline Sex & -0.001 & -0.001 \\
& $(0.003)$ & $(0.003)$ \\
\hline Education & 0.001 & 0.000 \\
& $(0.000)$ & $(0.000)$ \\
\hline Upper East Region & $-0.015^{* * *}$ & $-0.018^{* * *}$ \\
& $(0.005)$ & $(0.005)$ \\
\hline Upper West Region & -0.004 & -0.004 \\
& $(0.007)$ & $(0.007)$ \\
\hline Constant & $0.018^{*}$ & $0.015^{*}$ \\
& $(0.008)$ & $(0.008)$ \\
\hline Observations & 107 & 107 \\
\hline R-squared & 0.166 & 0.0127 \\
\hline Notes: *** p $<0.01, * * p<.05, * 0.1 ;$ Cluster robust standard errors in parentheses \\
\hline
\end{tabular}


Other significant variables that correlate with time preference in our model are plot location, main crop, and regional location. Being allocated to a head-end plot has a significant positive association with time preference of farmers. Controlling for other factors relating to time preferences, head-enders' time preferences are on average 0.9 percentage points higher than those of farmers with plots located elsewhere in the scheme. Head-end plots are economically advantaged in terms of water access and quality of infrastructure, as they are mostly the first to be allocated water for irrigation. It therefore takes less surveillance to ensure timely supply of water for effective production and one would have wished that farmers allocated to such plots will have more patience but this is contrary to that. Farmers at the tailend plots have the expected positive association but insignificant in determining time preferences.

Main type of crop grown in a scheme is also found to have a significant association with time preference. The results indicate that, assuming other factors remain constant, time preferences of tomatoes and onions farmers are 1.0 and 1.7 respective percentage points higher than pepper farmers in the surveyed schemes. Vegetable farmers (particularly tomatoes farmers) face a lot of marketing challenges in northern Ghana due to a lack of functional processing and storage facilities in the area. The farmers mostly rely on "market queens" (middle men) to sell their produce. Farmers in most schemes visited expressed the frustration they go through to sell their produce and the low prices they often receive due to the perishable nature of most vegetables.

The regional location of schemes is also found to affect time preferences. Farmers located in the Upper East Region have significantly lower time preferences, controlling for other factors, than farmers located in the other two regions. The estimated mean difference is 1.5 percentage points. Many cultural differences exist between different regions in Ghana, and this may affect time preference, as discussed in Wang et al. (2016). We did not examine the impact of these cultural dimensions in more detail in this study.

\section{CONCLUSION}

In northern Ghana, small-scale irrigation schemes have been constructed as a measure to reduce poverty. These schemes are mostly managed by Water User Associations (WUAs), and proper maintenance of these schemes is important for sustainable production. Being a common pool resource, the maintenance of these schemes is a collective effort by WUA members. We argue that the labour contributions of users to this effect are related to how positive the governing strategies of WUAs are perceived by the users. We also explain that labour contribution is a form of investment with expected future returns and, therefore, is related to the time preference of a user. We explore these correlations using cross-section data from a survey, and data from a field experiment that elicits time preferences of irrigation farmers in northern Ghana. The analysis and conclusion is drawn from 107 observations (59\% of the sample) which reflect consistent choices in the time preference experiment (see Appendix 1).

We find that governance perceptions relate to labour contributions towards maintenance. Irrigation farmers who perceive governance to be good are found to participate more in maintenance activities than those who perceive otherwise. Though the associated influence of governance is generally regarded as positive, as indicated by the overall governance perception, different dimensions of governance score differently. Six governance dimensions have been studied. Among these, conflict management and equity and fairness dimensions are found to have positive and significant associations with labour contributions. In other words, users who perceive that governing strategies on conflict management and equity and fairness are carried out well generally contribute more to maintaining irrigation resources.

The link between time preference and labour contribution is negative. Impatient farmers (i.e., those with high time preferences) on average contribute less to irrigation maintenance but this is not statistically significant from zero. We also examined factors associated with differences in time preferences as obtained from the field experiment. Our findings confirm a negative and significant correlation between household wealth and time preferences. They also suggest that farmers with plots in the head-ends and farmers growing tomatoes or onions tend to have relatively high time preferences while farmers located in the Upper East Region have low time preferences. 
Our results also highlight other factors that associate with labour contributions, in addition to governance perceptions. We find that age, education, head-end plots, and being located in the Upper East Region have significant, negative relations to labour contributions. Plot size, and growing tomatoes or onions as main crops associate positively with labour contribution.

We conclude that it is important for WUAs to note that their governing principles, regarding conflict management and equity and fairness in particular, influence how much labour each member willingly contributes to maintenance. Ensuring that conflicts are resolved to the satisfaction of all parties involved and being unbiased in the distribution of irrigation resources should therefore be encouraged. It is also important that WUAs observe and encourage activities that can improve water availability to minimise water related conflicts whiles ensuring equity and fairness. An example can be to resort to ground water use. A lot of water is wasted through the canal systems due to seepage. Farmers can be assisted to construct ground water structures where surface water reservoirs only serve as recharging facilities. This makes the irrigation facilities semi-communal thereby reducing water related conflicts while motivating high labour investments to maintain irrigation systems.

In terms of research recommendations, the fact that 73 observations ( $41 \%$ of the sample) in the time preferences experiment had to be dropped, as they made implausible choices, may to a certain extent have affected the results. Results of a Probit analysis exploring the underlying factors (see Appendix 3) indicate that farmers with relatively high household wealth and low mobility are significantly more likely to show irrational behaviour in the experiment. Future studies using Convex Time Budget (CTB) games for soliciting time preferences, like we used, are therefore advised to explore ways in which the high drop-out rates of farmers with relatively high wealth and low mobility can be reduced.

\section{ACKNOWLEDGEMENTS:}

This paper is part of a $\mathrm{PhD}$ study on "Irrigation governance in northern Ghana" carried out in Wageningen University and Research to whom we duly acknowledge. We also acknowledge Kees Burger (of blessed memory), for his contribution in the initial design of the study. To Zihan Nie, we thank you for assisting us to analyse the time preference data.

\section{REFERENCES}

Andersen, S., Harrison, G. W., Lau, M. I., \& Rutström, E. E. (2008). Eliciting Risk and Time Preferences. Econometrica, 76(3), 583-618.

Andreoni, J., Kuhn, M. A., \& Sprenger, C. (2013). Measuring Time Preferences (NBER Working Paper Series No. 19392). Cambridge: National Bureau of Economic Research.

Andreoni, J., \& Sprenger, C. (2010). Estimating Time Preferences from Convex Budgets. Cambridge: National Bureau of Economic Research.

Andreoni, J., \& Sprenger, C. (2012). Estimating Time Preferences from Convex Budgets. American Economic Review, 102(7), 3333-3356.

Becker, G. S., \& Mullingan, C. B. (1997). The Endogenous Determination of Time Preference. The Quarterly Journal of Economics, 112(3), 729-758

Birner, R., Schiffer, E., Asante, F., Gyasi, O., \& McCarthy, N. (2005). Report on Governance Structures for Water Resources Management in the White Volta Basin Ghana. Project "Integrating Governance and Modeling" Challenge Program on Water and Food. Washington DC, USA: IFPRI.

Bravo, G., \& Marelli, B. (2008). Irrigation Systems as Common-pool Resources. Journal of Alpine Research, 96(3), 15-26.

Cagetti, M. (2003). Wealth Accumulation Over the Life Cycle and Precautionary Savings. Journal of Business and Economic Statistics, 21(3), 339-353.

Charness, G., \& Viceisza, A. (2011). Comprehension and risk elicitation in the field: evidence from rural Senegal. mimeo. 
Dittoh, S., Bhattarai, M., \& Akuriba, M. A. (2013). Micro Irrigation-Based Vegetable Farming for Income, Employment and Food Security in West Africa. In M. A. Hanjra (Ed.), Global Food Security (pp. 177-199). Nova Science Publishers, Inc.

Dreyfus, M. K., \& Viscusi, W. K. (1995). Rates of Time Preference and Consumer Valuations of Automobile Safety and Fuel Efficiency. The Journal of Law and Economics, 38(1), 79-105.

Duflo, E., Kremer, M., \& Robinson, J. (2011). Nudging Farmers to Use Fertilizer: Theory and Experimental Evidence from Kenya. American Economic Review, 101(6), 2350-2390.

Duquette, E., Higgins, N. A. H., \& Horowitz, J. (2011). Farmer Discount Rates: Experimental Evidence. American Journal of Agricultural Economics, 94(2), 451-456.

Frederick, S., Loewenstein, G., \& O'Donoghue, T. (2002). Time Discounting and Preference: A Critical Time Review. Journal of Economic Literature, 40(2), 351-401.

Gachunga, J. M., \& Kuso, Y. (2019). Contribution of Infrastructure to Economic Growth in Africa. International Journal of Business Marketing and Management (IJBMM), 4, 43-51.

Gliem, J. A., \& Gliem, R. R. (2003). Calculating, Interpreting, and Reporting Cronbach' s Alpha Reliability Coefficient for Likert-Type Scales. In 2003 Midwest Research to Practice Conference in Adult, Continuing, and Community Education (pp. 82-88). Columbus.

Godoy, R., Jacobson, M., Castro, J. De, Aliaga, V., Romero, J., Godoy, R., .. \& Davis, A. (1998). The Role of Tenure Security and Private Time Preference in Neotropical Deforestation. Land Economics, 74(2), 162-170.

GSS (Ghana Statistical Service). (2014). Ghana Living Standards Survey Round 6 (GLSS6): Main Report, Accra. Ghana Statistical Service.

GWP (Global Water Partnership). (2009). Assessment of Water Governance in Ghana. Ouagadougou, Burkina Faso. Global Water Partnership West Africa.

Hausman, J. A. (1979). Individual Discount Rates and the Purchase and Utilization of Energy-using Durables. The Bell Journal of Economics, 10(1), 33-54.

Herrera, P. M., Davies, J., \& Baena, P. M. (2014). Governance of the Rangelands in a Changing World. In P. M. Herrera, J. Davies, \& P. M. Baena (Eds.), The Governance of Rangelands: Collective Action for Sustainable Pastoralism (pp. 32-44). New York: Routledge.

Holden, S. T., Shiferaw, B., and Wik, M. (1998). Poverty, Market Imperfections and Time Preferences: Of Relevance for Environmental policy? Environment and Development Economics, 3, 105-130.

Jacobson, S., \& Petrie, R. (2009). Learning from Mistakes: What Do Inconsistent Choice over Risk Tell Us? Journal of Risk and Uncertainty, 38(2), 143-58.

Lamptey, D., Nyamdi, B., \& Minta, A. (2011). National Irrigation Policy, Strategies and Regulatory Measures. Ghana Irrigation Development Authority, Accra, Ghana.

Lautze, J., Silva, S. De, Giordano, M., Sanford, L., \& De Silva, S. (2011). Putting the Cart Before the Horse:Water governance and IWRM. Natural Resources Forum, 35(1), 1-8.

Mansungu, E. (2004). Water For All: Improving Water Resource Governance in Southern Africa. Gatekeeper Series No. 113. London: International Institute for Environment and Development.

McCulloch, C. E. (2000). Generalized Linear Models. Journal of the American Statistical Association, 95(452), 1320-1324.

Meier, S., \& Sprenger, C. (2010). Present-Biased Preferences and Credit Card Borrowing. American Economic Journal: Applied Economics, 2(1), 193-210.

Mengistie, D., \& Kidane, D. (2016). Assessment of the Impact of Small-Scale Irrigation on Household Livelihood Improvement at Gubalafto District, North Wollo, Ethiopia. Agriculture, 6(3), 27.

Mul, M., Obuobie, E., Appoh, R., Kankam, K., Bekoe-obeng, E., Amisigo, B., .. \& Mccartney, M. (2015). Water Resources Assessment of the Volta River Basin. IWMI Working Paper No. 166. Colombo, Sri Lanka.

Mutambara, S., Darkoh, M. B. K., \& Atlhopheng, J. R. (2016). A Comparative Review of Water Management Sustainability Challenges in Smallholder Irrigation Schemes in Africa and Asia. Agricultural Water Management, 171, 63-72. 
Nagrah, A., Chaudhry, A. M., and Giordano, M. (2016). Collective Action in Decentralized Irrigation Systems: Evidence from Pakistan. World Development, 84, 282-298.

Namara, R. E., Horowitz, L., Nyamadi, B., \& Barry, B. (2011). Irrigation Development in Ghana: Past experiences, emerging opportunities, and future directions. Ghana Strategy Support Program (GSSP) Working Papers No. 27. Accra.

Oates, N., Jobbins, G., Mosello, B., \& Arnold, J. (2015). Pathways for irrigation development in Africainsights from Ethiopia, Morocco and Mozambique. Future Agricultures Working Paper 119. Retrieved from https://www.future-agricultures.org/download/fac-working-paper-119-pdf/

Ostrom, E. (2000). Reformulating the Commons. Swiss Political Science Review, 6(1), 29-52.

Ostrom, E., \& Gardner, R. (1993). Coping with Asymmetries in the Commons: Self-governing Irrigation Systems Can Work. The Journal of Economic Perspectives, 7(4), 93-112.

Shiferaw, B. A., Okello, J., \& Reddy, R. (2009). Adoption and Adaptation of Natural Resource Management Innovations in Smallholder Agriculture: Reflections on Key Lessons and Best Practices. Environment Development and Sustainability, 11, 601-619.

Silverman, I. W. (2003). Gender Differences in Delay of Gratification: A Meta-Analysis. Sex Roles, 49(9/10), 451-452.

Sullivan, G. M., \& Artino, A. R., Jr. (2013). Analyzing and Interpreting Data From Likert-Type Scales. Journal of Graduate Medical Education, 5(4), 541-542.

Svendsen, M., Ewing, M., and Msangi, S. (2009). Measuring Irrigation Performance in Africa. IFPRI Discussion Paper No. 894. Washington DC, USA.

Tanaka, Y., and Munro, A. (2012). Regional Variation in Risk and Time Preferences: Evidence From a Large-Scale Field Experiment in Rural Uganda. Tokyo, Japan: National Graduate Institute for Policy Studies.

Tortajada, C. (2010). Water Governance: Some Critical Issues. International Journal of Water Resources Development, 26(2), 297-307.

van Edig, A., Engel, S., \& Laube, W. (2003). Ghana's Water Institutions in the Process of Reform: from the International to the Local Level. In S. Neubert, W. Scheumann, \& A. Van Edig (Eds.), Reforming Institutions for Sustainable Water Management (pp. 31-51). Bonn, Germany: German Development Institute.

Wang, M., Oliver, M., \& Hens, T. (2016). How Time Preferences Differ: Evidence from 53 Countries. Journal of Economic Psychology, 52, 115-135.

Wang, M., Rieger, M. O., \& Hens, T. (2011). How Time Preferences Differ: Evidence from 45 Countries. Institute for Foretaksokonomi.

Wiek, A., \& Larson, K. L. (2012). Water, People, and Sustainability - A Systems Framework for Analyzing and Assessing Water Governance Regimes. Water Resources Development, 26, 31533171

Yesuf, M. (2004). Risk, Time and Land Management Under Market Imperfections: Applications to Ethiopia. Göteborg: Thesis. Göteborg University.

Yu, H. H., Edmunds, M., Lora-Wainwright, A., \& Thomas, D. (2016). Governance of the Irrigation Commons under Integrated Water Resources Management - A Comparative Study in Contemporary Rural China. Environmental Science and Policy, 55, 65-74. 


\section{APPENDICES}

\section{APPENDIX 1 \\ CONVEX TIME BUDGET (CTB) DESIGN}

The experimental design had 15 convex budgets in which participants had to make choices over how to allocate 50 tokens between two points in time, one time being earlier, $t$, and the other being later, $t+k$. The later points in time varied across decisions to allow for time discounting. A $(1 \times 3)$ design approach was used by crossing the earlier payment date, $t=7$ with three delay periods, $k=(21,49,77)$. In all, there were three $(t, t+k)$ cells, with each cell having five CTB choices, making a total of 15 choices per subject (Table 1.1). Unlike in Andreoni and Sprenger (2010, 2012), the earliest time to receive payments in our experiment was seven (7) days from the day of the experiment. This was to avoid present bias and to simplify the estimation methods since our interest was in discount rates. To avoid differential weekday effects, $t$ and $k$ were both multiples of 7 . Tokens allocated to earlier and later payments had values of $\mathrm{a}_{t}$ and $\mathrm{a}_{t+k}$ respectively. Values of $\mathrm{a}_{t}$ varied from GHCO 10 to GHCO.30, while $\mathrm{a}_{t+k}$ had a value of GHCO.40 in all cases (making the future-value budget, $m$, GHC20.00). The gross interest rate over $k$ days was $a_{t+k}$ $/ \mathrm{a}_{t}=1+r$, so that the standardized daily net interest rate was $(1+r)^{1 / k}-1$. Table 1.1 presents details of the choice sets that were used.

TABLE 1.1 CONVEX TIME BUDGET CHOICE SETS

\begin{tabular}{cccccccc}
\hline $\begin{array}{c}\mathrm{t} \\
\begin{array}{c}\text { earlier } \\
\text { date) }\end{array}\end{array}$ & $\begin{array}{c}\mathrm{k} \\
\text { (delay) }\end{array}$ & Tokens & $\mathrm{a}_{t}$ & $\mathrm{a}_{t+k}$ & $(1+r)$ & $\begin{array}{c}\text { Daily net } \\
\text { interest } \\
\text { rates } \\
\text { (percent) }\end{array}$ & $\begin{array}{c}\text { Quarterly } \\
\text { compounded } \\
\text { annual rate } \\
\text { (percent) }\end{array}$ \\
\hline 7 & 21 & 50 & 0.30 & 0.4 & 1.33 & 1.38 & 2502.5 \\
7 & 21 & 50 & 0.25 & 0.4 & 1.60 & 2.26 & 8728.6 \\
7 & 21 & 50 & 0.20 & 0.4 & 2.00 & 3.36 & 27128.4 \\
7 & 21 & 50 & 0.15 & 0.4 & 2.67 & 4.78 & 82626.0 \\
7 & 21 & 50 & 0.10 & 0.4 & 4.00 & 6.82 & 272700.6 \\
7 & 49 & 50 & 0.30 & 0.4 & 1.33 & 0.59 & 458.5 \\
7 & 49 & 50 & 0.25 & 0.4 & 1.60 & 0.96 & 1147.8 \\
7 & 49 & 50 & 0.20 & 0.4 & 2.00 & 1.42 & 2698.3 \\
7 & 49 & 50 & 0.15 & 0.4 & 2.67 & 2.02 & 6450.8 \\
7 & 49 & 50 & 0.10 & 0.4 & 4.00 & 2.87 & 17043.8 \\
7 & 77 & 50 & 0.30 & 0.4 & 1.33 & 0.37 & 223.9 \\
7 & 77 & 50 & 0.25 & 0.4 & 1.60 & 0.61 & 490.3 \\
7 & 77 & 50 & 0.20 & 0.4 & 2.00 & 0.90 & 1009.6 \\
7 & 77 & 50 & 0.15 & 0.4 & 2.67 & 1.28 & 2116.5 \\
7 & 77 & 50 & 0.10 & 0.4 & 4.00 & 1.82 & 4889.3 \\
\hline
\end{tabular}

The game was repeated for $t=14,28$ days giving a total of 45 choices per farmer. Unfortunately, only $t=7$ can be used in the analysis due to an error in the design when all 45 choices are considered. When all 45 decisions had been made, we randomly selected one of the 45 decisions to determine actual earnings of participants. Subjects were assigned to research assistants to help in record keeping but decisions were solely the responsibility of the subjects. Time was allowed for participants to ask questions for clarification before the experiment was performed. Each participant was given GHC3.00 at the end as a "thank you" for taking part in the study. 
The values of $\mathrm{a}_{t}$ and $\mathrm{a}_{t+k}$ were chosen to accommodate the fact that interest rates in Ghana are relatively high due to the rapid inflation and the resultant depreciation of the Ghana Cedi. To make the game understandable and realistic in terms of market value, the chosen daily and annual interest rates were higher than those used by Andreoni and Sprenger (2012).

Following Andreoni and Sprenger (2012), we estimated the discount factor from the data set obtained through the experiment. From the experimental design, the future-value budget constraint is

$$
(1+r) c_{t}+c_{t+k}=m
$$

where

$$
\begin{array}{ll}
c_{t} & =\text { experimental earnings at earlier time }, t \\
c_{t+k} & =\text { experimental earnings at a later time }, t+k \\
(l+r) & =\text { experimental gross interest rate } \\
m & =\text { experimental budget }
\end{array}
$$

We posit a time separable constant relative risk aversion (CRRA) utility function discounted by the quasi-hyperbolic $\delta$ discounting function

$$
U\left(c_{t}, c_{t+k}\right)=\left(c_{t}-w_{1}\right)^{\alpha} / \alpha+\delta^{k}\left(c_{t+k}-w_{2}\right)^{\alpha} / \alpha
$$

where

$$
\begin{array}{ll}
\delta & =\text { daily discount factor } \\
\alpha & =\text { CRRA curvature parameter } \\
w_{1}, w_{2} & =\text { background consumption }
\end{array}
$$

Maximizing (2) subject to the budget constraint (1) gives the tangency condition

$\frac{c_{t}-w_{1}}{c_{t+k}-w_{2}}=\left(\delta^{k}(1+r)\right)^{\frac{1}{\alpha-1}}, \quad$ if $t>0$

and an intertemporal formulation of a Stone-Geary linear demand for $C_{t}$,

$C_{t}=\left[\frac{1}{1+(1+r)\left(\delta^{k}(1+r)\right)^{\left(\frac{1}{\alpha-1}\right)}}\right] w_{1}+\left[\frac{\left(\delta^{k}(1+r)^{\left(\frac{1}{\alpha-1}\right)}\right.}{1+(1+r)\left(\delta^{k}(1+r)\right)^{\left(\frac{1}{\alpha-1}\right)}}\right]\left(m-w_{2}\right)$

Equation (4) and the parameters $\delta, \alpha, w_{l}$, and $w_{2}$ are estimated using nonlinear least squares. Also, linearizing (3) gives

$\ln \left(\frac{c_{t}-w_{1}}{c_{t+k}-w_{2}}\right)=\left(\frac{\ln \delta}{\alpha-1}\right) \cdot k+\left(\frac{1}{\alpha-1}\right) \cdot \ln (1+r) \quad$ if $t>0$

which can be written as

$\ln \left(\frac{c_{t}-w_{1}}{c_{t+k}-w_{2}}\right)=\gamma_{1} k+\gamma_{2} \ln (1+r) \quad$ if $t>0$

Given an additive error structure and projected background consumption, equation (6) can be estimated using a two-limit censored Tobit regression to take care of the censoring nature of the data.

From (5) and (6), $\alpha=\frac{1}{\gamma_{2}}+1, \quad$ and $\delta=\exp \left(\frac{\gamma_{1}}{\gamma_{2}}\right)$ is the daily discount factor. The daily rate of time preference, denoted by $\theta$, follows from the daily discount factor: 
$\theta=\frac{1}{\delta}-1$

From GSS (2014, p 136), the mean annual household expenditure for both food and non-food in the three regions are: Northern $(\mathbb{C} 7,153)$, Upper East $(\mathbb{C} 6,210)$, and Upper West $(\mathbb{C} 5,991)$, giving an average of $\mathbb{C} 6,451.33$ for the study area. This implies a daily household consumption of $\mathbb{C} 17.67$. We therefore use $\mathbb{C} 18.00$ (an equivalent of about $\$ 7.65$ as at January 2014) as the background consumption in the Tobit estimates. Thus $w_{1}=w_{2}=-18$. Table 1.2 presents the aggregate estimates using NLS and two-limit Tobit regressions (for $w_{1}=w_{2}=-0.01$ and $w_{1}=w_{2}=-18$ ). Aggregate estimation results are sensitive to the estimation methods and the assumption about the background parameters as indicate in the table. Table 1.3 summarizes the individual discounting and curvature parameter estimates from the NLS approach (with $w_{1}=w_{2}=0$ ).

TABLE 1.2

AGGREGATE ESTIMATES FROM SUB-SAMPLE OF NO MULTIPLE SWITCHING AND WITH VALID INDIVIDUAL LEVEL ESTIMATES (107 PARTICIPANTS)

\begin{tabular}{|c|c|c|c|c|c|c|}
\hline & $\begin{array}{l}(1) \\
\text { NLS }\end{array}$ & $\begin{array}{l}(2) \\
\text { NLS }\end{array}$ & $\begin{array}{l}(3) \\
\text { NLS }\end{array}$ & $\begin{array}{c}(4) \\
\text { Tobit }\end{array}$ & $\begin{array}{l}(5) \\
\text { NLS }\end{array}$ & $\begin{array}{l}(6) \\
\text { Tobit }\end{array}$ \\
\hline CRRA curvature: $\alpha$ & $\begin{array}{l}0.649^{* * *} \\
(0.0271)\end{array}$ & $\begin{array}{l}0.644^{* * *} \\
(0.0487)\end{array}$ & $\begin{array}{l}0.661^{* * *} \\
(0.0216)\end{array}$ & $\begin{array}{l}0.945^{* * *} \\
(0.00745)\end{array}$ & $\begin{array}{l}-0.436^{* * *} \\
(0.0603)\end{array}$ & $\begin{array}{l}0.390^{* * *} \\
(0.0730)\end{array}$ \\
\hline Annual discount rate & $\begin{array}{l}3.873^{* *} \\
(1.583)\end{array}$ & $\begin{array}{l}46.03^{* * *} \\
(12.24)\end{array}$ & $\begin{array}{l}45.97^{* * *} \\
(12.14)\end{array}$ & $\begin{array}{l}203.4^{* * *} \\
(72.31)\end{array}$ & $\begin{array}{l}47.80^{* * *} \\
(12.08)\end{array}$ & $\begin{array}{l}122.5^{* * *} \\
(39.78)\end{array}$ \\
\hline$w_{1}$ & $\begin{array}{c}0.102 \\
(0.264)\end{array}$ & $\begin{array}{l}-0.248 \\
(0.453)\end{array}$ & & & & \\
\hline$w_{2}$ & $\begin{array}{l}-9.770^{* * *} \\
(2.105)\end{array}$ & & & & & \\
\hline $\begin{array}{l}w_{1}=w_{2} \\
\text { Daily discount factor: } \delta\end{array}$ & $\begin{array}{c}- \\
0.996^{* * *} \\
(0.000886 \\
)\end{array}$ & $\begin{array}{c}- \\
0.990^{* * *} \\
(0.000706 \\
)\end{array}$ & $\begin{array}{c}0 \\
0.990^{* * *} \\
(0.000701 \\
)\end{array}$ & $\begin{array}{c}-0.01 \\
0.986^{* * *} \\
(0.000955 \\
)\end{array}$ & $\begin{array}{c}-18 \\
0.989^{* * *} \\
(0.000671 \\
)\end{array}$ & $\begin{array}{c}-18 \\
0.987^{* * *} \\
(0.000871 \\
)\end{array}$ \\
\hline Observations & 1605 & 1605 & 1605 & 1605 & 1605 & 1605 \\
\hline
\end{tabular}

Notes: Standard errors in parentheses, ${ }^{*} p<0.10,{ }^{* *} p<0.05,{ }^{* * *} p<0.01$

TABLE 1.3

INDIVIDUAL DISCOUNTING AND CURVATURE PARAMETER ESTIMATES

\begin{tabular}{|l|l|l|l|l|l|l|}
\hline & $\mathrm{N}$ & Median & $5^{\text {th }}$ percentile & $\begin{array}{l}95^{\text {th }} \\
\text { percentile }\end{array}$ & Min & Max \\
\hline $\begin{array}{l}\text { Daily discount } \\
\text { factor: delta }\end{array}$ & 107 & 0.9879 & 0.9468 & 1.0072 & 0.8904 & 1.0125 \\
\hline Curvature: alpha & 107 & 0.8478 & -0.6429 & 0.9977 & -2.6579 & 0.9990 \\
\hline
\end{tabular}

Notes: Estimated with non-linear least squares (NLS) with $w_{l}=w_{2}=0$. 


\section{APPENDIX 2 \\ OLS AND GLM REGRESSION RESULTS FOR LABOUR CONTRIBUTIONS}

\begin{tabular}{|c|c|c|c|c|}
\hline & $\begin{array}{l}\text { 1. OLS overall } \\
\text { governance }\end{array}$ & $\begin{array}{l}\text { 2. OLS gov. } \\
\text { dimensions }\end{array}$ & $\begin{array}{l}\text { 3. GLM overall } \\
\text { governance }\end{array}$ & $\begin{array}{l}\text { 4. GLM gov } \\
\text { dimensions }\end{array}$ \\
\hline $\begin{array}{l}\text { Overall governance } \\
\text { Perception }\end{array}$ & $\begin{array}{l}1.116^{* * *} \\
(0.385)\end{array}$ & & $\begin{array}{l}1.116 * * * \\
(0.357)\end{array}$ & \\
\hline Participation & & $\begin{array}{l}0.043 \\
(0.378)\end{array}$ & & $\begin{array}{l}0.043 \\
(0.341)\end{array}$ \\
\hline Accountability & & $\begin{array}{l}0.058 \\
(0.361)\end{array}$ & & $\begin{array}{l}0.058 \\
(0.325) \\
\end{array}$ \\
\hline $\begin{array}{l}\text { Conflict } \\
\text { Management }\end{array}$ & & $\begin{array}{l}0.731^{*} \\
(0.398)\end{array}$ & & $\begin{array}{l}0.731 * * \\
(0.358)\end{array}$ \\
\hline $\begin{array}{l}\text { Transparency and } \\
\text { Cooperation }\end{array}$ & & $\begin{array}{l}0.427 \\
(0.474)\end{array}$ & & $\begin{array}{l}0.427 \\
(0.427)\end{array}$ \\
\hline Equity and fairness & & $\begin{array}{l}0.660 * * \\
(0.287)\end{array}$ & & $\begin{array}{l}0.660 * * \\
(0.258)\end{array}$ \\
\hline Sustainable use & & $\begin{array}{l}0.306 \\
(0.296)\end{array}$ & & $\begin{array}{l}0.306 \\
(0.266)\end{array}$ \\
\hline Time preference & $\begin{array}{l}-4.326 \\
(5.072)\end{array}$ & $\begin{array}{l}-5.295 \\
(5.261) \\
\end{array}$ & $\begin{array}{l}-4.326 \\
(4.699)\end{array}$ & $\begin{array}{l}-5.295 \\
(4.739) \\
\end{array}$ \\
\hline Age & $\begin{array}{l}-0.022^{* *} \\
(0.010)\end{array}$ & $\begin{array}{l}-0.024^{* *} \\
(0.010)\end{array}$ & $\begin{array}{l}-0.022 * * \\
(0.009)\end{array}$ & $\begin{array}{l}-0.024 * * * \\
(0.009)\end{array}$ \\
\hline Sex & $\begin{array}{l}-0.349 \\
(0.242)\end{array}$ & $\begin{array}{l}-0.345 \\
(0.249)\end{array}$ & $\begin{array}{l}-0.349 \\
(0.224)\end{array}$ & $\begin{array}{l}-0.345 \\
(0.225)\end{array}$ \\
\hline Education & $\begin{array}{l}-0.073 * * * \\
(0.023)\end{array}$ & $\begin{array}{l}-0.074 * * * \\
(0.024)\end{array}$ & $\begin{array}{l}-0.073 * * * \\
(0.021) \\
\end{array}$ & $\begin{array}{l}-0.074 * * * \\
(0.022)\end{array}$ \\
\hline $\begin{array}{l}\text { Household labour } \\
\text { Force }\end{array}$ & $\begin{array}{l}-0.008 \\
(0.054)\end{array}$ & $\begin{array}{l}0.001 \\
(0.064)\end{array}$ & $\begin{array}{l}-0.008 \\
(0.050)\end{array}$ & $\begin{array}{l}0.001 \\
(0.058)\end{array}$ \\
\hline Plot size & $\begin{array}{l}1.573 \\
(1.160) \\
\end{array}$ & $\begin{array}{l}1.786 \\
(1.162)\end{array}$ & $\begin{array}{l}1.573 \\
(1.075)\end{array}$ & $\begin{array}{l}1.786^{*} \\
(1.047)\end{array}$ \\
\hline Group size & $\begin{array}{l}0.006 \\
(0.005)\end{array}$ & $\begin{array}{l}0.007 \\
(0.005)\end{array}$ & $\begin{array}{l}0.006 \\
(0.005)\end{array}$ & $\begin{array}{l}0.007 \\
(0.005)\end{array}$ \\
\hline Age of scheme & $\begin{array}{l}0.011 \\
(0.007)\end{array}$ & $\begin{array}{l}0.007 \\
(0.008)\end{array}$ & $\begin{array}{l}0.011 \\
(0.007)\end{array}$ & $\begin{array}{l}0.007 \\
(0.008)\end{array}$ \\
\hline Head-end plot & $\begin{array}{l}-1.275^{* * *} \\
(0.285)\end{array}$ & $\begin{array}{l}-1.189^{* * *} \\
(0.227)\end{array}$ & $\begin{array}{l}-1.275^{* * *} \\
(0.264)\end{array}$ & $\begin{array}{l}-1.189^{* * *} \\
(0.204)\end{array}$ \\
\hline Tail-end plot & $\begin{array}{l}0.120 \\
(0.396)\end{array}$ & $\begin{array}{l}0.096 \\
(0.399)\end{array}$ & $\begin{array}{l}0.120 \\
(0.367)\end{array}$ & $\begin{array}{l}0.096 \\
(0.359)\end{array}$ \\
\hline Tomatoes & $\begin{array}{l}1.988 * * * \\
(0.282)\end{array}$ & $\begin{array}{l}2.101^{* * *} \\
(0.274)\end{array}$ & $\begin{array}{l}1.988^{* * *} \\
(0.262)\end{array}$ & $\begin{array}{l}2.101^{* * *} \\
(0.247)\end{array}$ \\
\hline Onions & $\begin{array}{l}1.313 * * * \\
(0.337)\end{array}$ & $\begin{array}{l}1.358 * * * \\
(0.363)\end{array}$ & $\begin{array}{l}1.313^{* * *} \\
(0.312)\end{array}$ & $\begin{array}{l}1.358 * * * \\
(0.327)\end{array}$ \\
\hline Upper East & $\begin{array}{l}-1.394^{* * *} \\
(0.317)\end{array}$ & $\begin{array}{l}-1.054 * * * \\
(0.359)\end{array}$ & $\begin{array}{l}-1.394^{* * *} \\
(0.293)\end{array}$ & $\begin{array}{l}-1.054^{* * *} \\
(0.323)\end{array}$ \\
\hline Upper West & $\begin{array}{l}0.923^{*} \\
(0.512)\end{array}$ & $\begin{array}{l}1.366^{* *} \\
(0.577)\end{array}$ & $\begin{array}{l}0.923^{*} \\
(0.475)\end{array}$ & $\begin{array}{l}1.366^{* * *} \\
(0.519)\end{array}$ \\
\hline Constant & $\begin{array}{l}-1.290 \\
(1.479)\end{array}$ & $\begin{array}{l}-5.056 \\
(2.968) \\
\end{array}$ & $\begin{array}{l}-1.290 \\
(1.370)\end{array}$ & $\begin{array}{l}-5.056^{*} \\
(2.673) \\
\end{array}$ \\
\hline Observations & 107 & 107 & 107 & 107 \\
\hline R-squared & 0.444 & 0.495 & & \\
\hline
\end{tabular}

Notes: ${ }^{* *} \mathrm{p}<0.01,{ }^{* *} \mathrm{p}<0.05,{ }^{*} \mathrm{p}<0.1$; Robust standard errors in parenthesis 


\section{APPENDIX 3 \\ PROBIT REGRESSION RESULTS OF BEING INCLUDED IN THE SAMPLE OF 107 PARTICIPANTS}

\begin{tabular}{|c|c|}
\hline Variable & Coefficients \\
\hline Age & $\begin{array}{l}0.005 \\
(0.008)\end{array}$ \\
\hline Sex & $\begin{array}{l}0.029 \\
(0.200)\end{array}$ \\
\hline Education & $\begin{array}{l}0.021 \\
(0.025)\end{array}$ \\
\hline Household wealth & $\begin{array}{l}-0.036^{* * *} \\
(0.012)\end{array}$ \\
\hline Christian & $\begin{array}{l}-0.064 \\
(0.177)\end{array}$ \\
\hline Muslim & $\begin{array}{l}-0.051 \\
(0.281)\end{array}$ \\
\hline Mobility & $\begin{array}{l}0.025^{* *} \\
(0.011) \\
\end{array}$ \\
\hline Constant & $\begin{array}{l}0.268 \\
(0.480)\end{array}$ \\
\hline Observations & 180 \\
\hline Wald chi2(7) & 14.96 \\
\hline Prob $>$ chi 2 & 0.0365 \\
\hline Pseudo R2 & 0.0389 \\
\hline Log pseudo likelihood & -116.80653 \\
\hline
\end{tabular}

